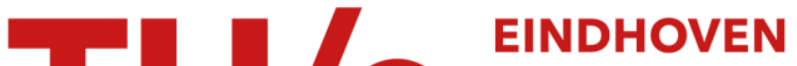 UNIVERSITY OF TECHNOLOGY
}

\section{The use of ternary phase diagram sections in solid-state reactions involving TiC formation}

Citation for published version (APA):

Ramaekers, P. P. J., Loo, van, F. J. J., Bastin, G. F., \& Metselaar, R. (1985). The use of ternary phase diagram sections in solid-state reactions involving TiC formation. Solid State lonics, 16, 179-184.

https://doi.org/10.1016/0167-2738(85)90041-4

DOI:

10.1016/0167-2738(85)90041-4

Document status and date:

Published: 01/01/1985

Document Version:

Publisher's PDF, also known as Version of Record (includes final page, issue and volume numbers)

Please check the document version of this publication:

- A submitted manuscript is the version of the article upon submission and before peer-review. There can be important differences between the submitted version and the official published version of record. People interested in the research are advised to contact the author for the final version of the publication, or visit the $\mathrm{DOI}$ to the publisher's website.

- The final author version and the galley proof are versions of the publication after peer review.

- The final published version features the final layout of the paper including the volume, issue and page numbers.

Link to publication

\section{General rights}

Copyright and moral rights for the publications made accessible in the public portal are retained by the authors and/or other copyright owners and it is a condition of accessing publications that users recognise and abide by the legal requirements associated with these rights.

- Users may download and print one copy of any publication from the public portal for the purpose of private study or research.

- You may not further distribute the material or use it for any profit-making activity or commercial gain

- You may freely distribute the URL identifying the publication in the public portal.

If the publication is distributed under the terms of Article 25fa of the Dutch Copyright Act, indicated by the "Taverne" license above, please follow below link for the End User Agreement:

www.tue.nl/taverne

Take down policy

If you believe that this document breaches copyright please contact us at:

openaccess@tue.nl

providing details and we will investigate your claim. 
THE USE OF TERNARY PHASE DIAGRAM SECTIONS IN SOLID-STATE REACTIONS INVOLVING TIC FORMATION

\author{
P.P.J. RAMAEKERS, F.J.J. VAN LOO, G.F. BASTIN and R. METSELAAR
}

Laboratory of Physical Chemistry, Eindhoven University of Technology, P.0. Box 513, 5600 MB Eindhoven, The Netherlands

Solid-state diffusion couples are used as simulation experiments to study the diffusional interaction between iron-carbon or cobalt-carbon substrates and titanium carbide coatings deposited by chemical vapour deposition. The plotting of diffusion paths on the ternary phase diagram cross sections $\mathrm{Fe}-\mathrm{Ti}-\mathrm{C}$ and $\mathrm{CO}-\mathrm{Ti}-\mathrm{C}$ reveals information concerning the solid-state diffusion process during this deposition.

A diffusion path illustrates only phenomenological features; for kinetic information composition profiles as a function of distance may be used.

\section{INTRODUCTION}

Titanium carbide (TiC) is used as a protective coating on tool parts for abrasive applications, with the main aim of improving their wear resistance. It can be deposited by means of chemical vapour deposition (CVD), a technique using the reactive gases $\mathrm{TiCl}_{4}$ and (mostly) $\mathrm{CH}_{4}$ as carbon source. Hydrogen is being employed as a carrier gas; all deposition experiments of $\mathrm{TiC}$ were performed at a temperature of 1273K. In CVD practice of TiC mostly steel or cemented carbide (Co-WC two-phase material) substrates are used, which also contribute carbon atoms to form the TiC coating. These kind of substrates have the clear advantage that the bonding between surface layer and substrate is greatiy enhanced because of the diffusional interaction. However, for the abrasive application of $\mathrm{TiC}$ coatings, this diffusional interaction could also turn into a disadvantage: in many cases the carbon containing substrate is strongly decarburized, which results in a decrease of hardness and mechanical strength ${ }^{1}$.

In this paper we will describe the phenomenology of the underlying diffusion process by plotting diffusion paths on ternary phase diagram cross sections. In our investigations we started with binary substrates only, viz. $\mathrm{Fe}_{100-y} \mathrm{C}_{y}$ and $\mathrm{Co}_{100-y^{C} y}$. This simplifying approach has the advantage that a ternary system has developed after the deposition of TiC on those substrates, so that the appropriate ternary phase diagrams $\mathrm{Fe}-\mathrm{Ti}-\mathrm{C}$ and $\mathrm{Co}-\mathrm{Ti}-\mathrm{C}$ can be used (in situations assuming thermodynamical equilibrium). Future research efforts are aimed at an extension towards the quaternary systems $\mathrm{Fe}-\mathrm{Cr}-\mathrm{Ti}-\mathrm{C}$ and $\mathrm{Co}-\mathrm{W}-\mathrm{Ti}-\mathrm{C}$, linking up with the CVD practice of coating steel or cobalt-based cemented carbide substrates with TiC.

This work is part of a research program with the aim of studying the kinetics of TiC formation by CVD (using $\mathrm{TiCl}_{4} / \mathrm{CH}_{4} / \mathrm{H}_{2}$ ) in relation to the diffusion processes involved ${ }^{2,3}$.

2. DETERMINATION OF PHASE DIAGRAM CROSS SECTIONS

The determination of the phase diagram cross sections in the systems $\mathrm{Fe}-\mathrm{Ti}-\mathrm{C}$ and Co-Ti-C at $1273 \mathrm{~K}$ has been described elsewhere ${ }^{4,5}$. The most important analysis technique we used in those investigations was electron probe microanalysis (EPMA). At this moment we will only present the $\mathrm{Fe}-\mathrm{Ti}-\mathrm{C}$ and Co-Ti-C cross sections at $1273 \mathrm{~K}$, see figs. 1,2: 


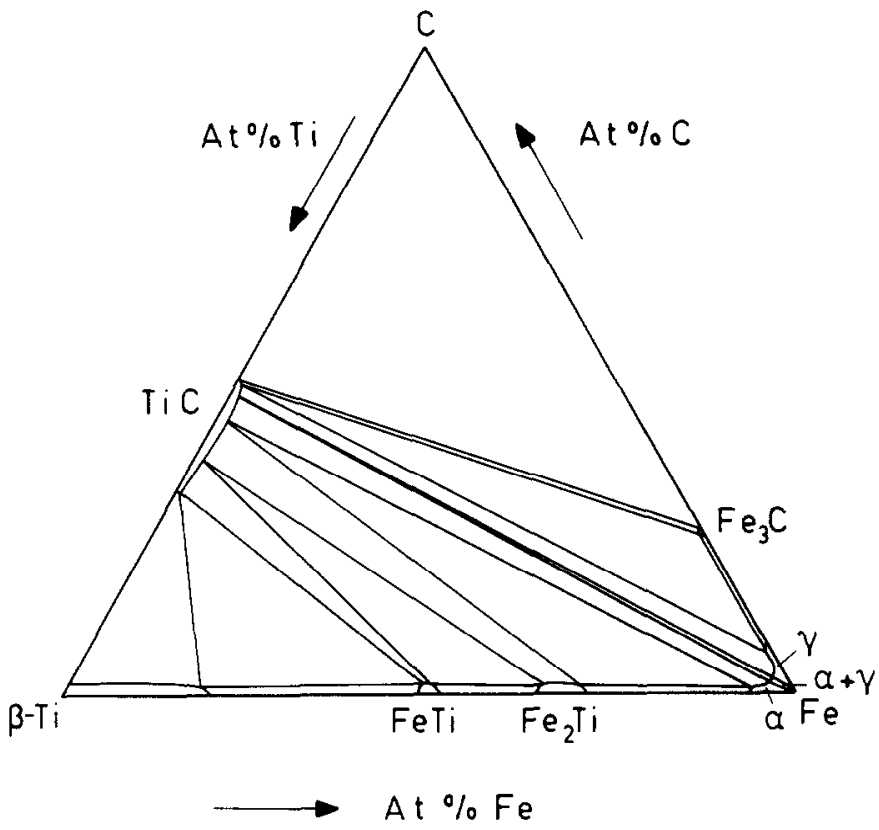

FIGURE 1.

Isothermal section of the phase diagram Fe-Ti-C at $1273 \mathrm{~K}$.

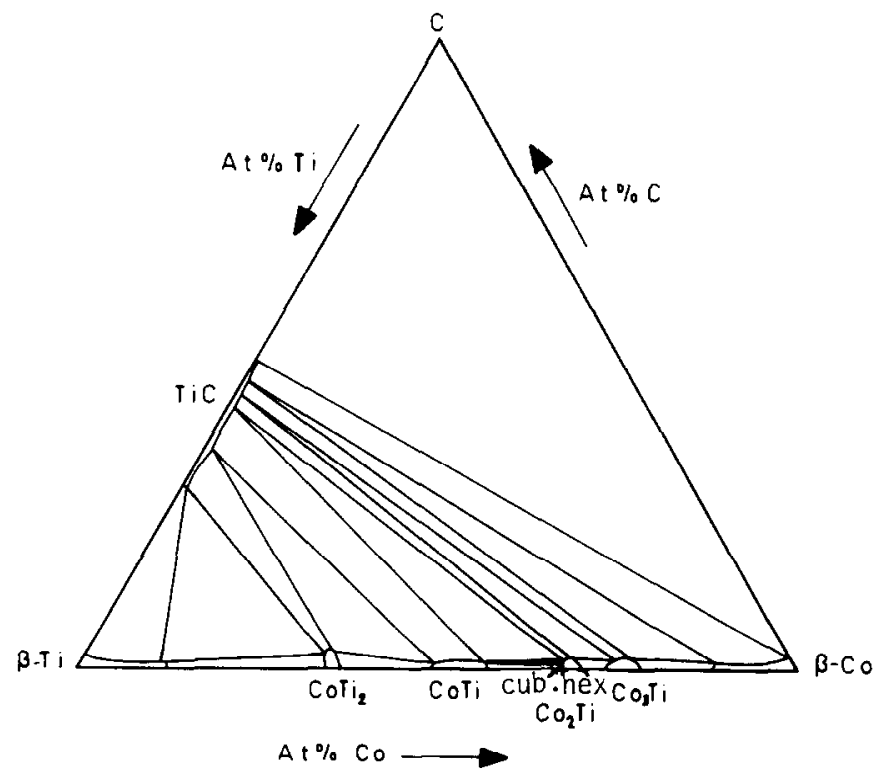

FIGURE 2.

Isothermal section of the phase diagram Co-Ti-C at $1273 \mathrm{~K}$. 
3. OBSERVED DIFFUSION PATHS; THE DIFFUSION COUPLE ANALOGY

To describe diffusional interactions between phases in ternary systems so-called diffusion paths can be plotted on the isothermal cross sections. A diffusion path represents the average concentration profile of the various elements in the diffusion zone. In single-phase materials this path coincides with the concentration profile: it is determined by measuring concentrations using point measurements (in our case obtained by EPMA). For multiphase materials, however, point measurements of concentrations are not sufficient to establish the course of a diffusion path. In that case concentrations have to be averaged in a lateral direction (perpendicular to the diffusion direction) to account for the presence of different phases. For the construction of diffusion paths we followed the rules proposed by Kirkaldy ${ }^{6}$ and conventionalized by $\mathrm{Clark}^{7}$.

For instance, a solid line crossing a single phase field denotes an existing layer of that phase in the diffusion couple. A dashed line crossing a two-phase field parallel to the tie lines represents an interface between the two phases with interfacial compositions designated by the ends of the tie line. Such a dashed line represents no spatial extent.

Constructed in this way diffusion paths give information about the phenomenology, that is to say the morphology and composition of a solidstate reaction zone. They do not, however, contain direct information of a kinetic nature.

Especially in case of multiphase ternary diffusion the diffusion path approach is very effective in describing the phenomenology of the reaction zone ${ }^{8}$. By plotting observed diffusion paths on isothermal cross sections of different ternary systems the course of these paths can be compared. This eventually could lead to a better understanding of the factors determining which of the (theoretical1y) possible diffusion pathways is chosen by nature. To illustrate this we may note that Rapp et a1. ${ }^{9}$ predicted in a similar way the morphology, and composition of diffusion reaction layers.

To construct diffusion paths in the systems $\mathrm{Fe}-\mathrm{Ti}-\mathrm{C}$ and $\mathrm{CO}-\mathrm{Ti}-\mathrm{C}$ solid state diffusion couples (heat-treated at 1273K) have been used as model experiments for CVD-treated samples. The excellent suitability of diffusion couples for simulation purposes has already been demonstrated for the Fe-Ti-C system ${ }^{5}$.

Diffusion couples Ti- $\mathrm{Fe}_{100-y^{C} y}$ and

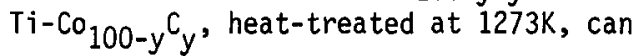
develop a reaction layer consisting of $\mathrm{TiC}$, when the iron-rich (or cobalt-rich) side of the couple is containing a sufficient amount of carbon. For $\mathrm{Ti}^{-}-\mathrm{Fe}_{100-y} \mathrm{C}_{\mathrm{y}}$ resp.

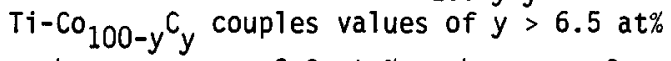
carbon resp. $y>2.0$ at.\% carbon were found 4,5 . For carbon contents lower than these values no closed TiC reaction layer is found, but interdiffusion of titanium and iron (or cobalt) takes place, the TiC being present as precipitates in one or more of the intermetallic phases.

The diffusion paths describing TiC formation for $T i-\mathrm{Fe}_{100}-\mathrm{y} \mathrm{C}_{\mathrm{y}}$ diffusion couples are given in figs. 3 and 4.

Figure 5 shows an enlargement of a section of figs. 3 and 4 . In this section the diffusion path is reflecting the decarburisation of the iron starting material which is responsible for $\mathrm{TiC}$ formation. For $\mathrm{Ti}^{-} \mathrm{CO}_{100-y} \mathrm{C}_{\mathrm{y}}$ couples the same course of diffusion paths is followed as described in figs. 3 and $4^{4}$. To compare the decarburisation in this case with that observed in $\mathrm{Ti}-\mathrm{Fe}_{100-\mathrm{y} \mathrm{C}}$ diffusion couples a cobalt-rich section is shown in figure 6 . 


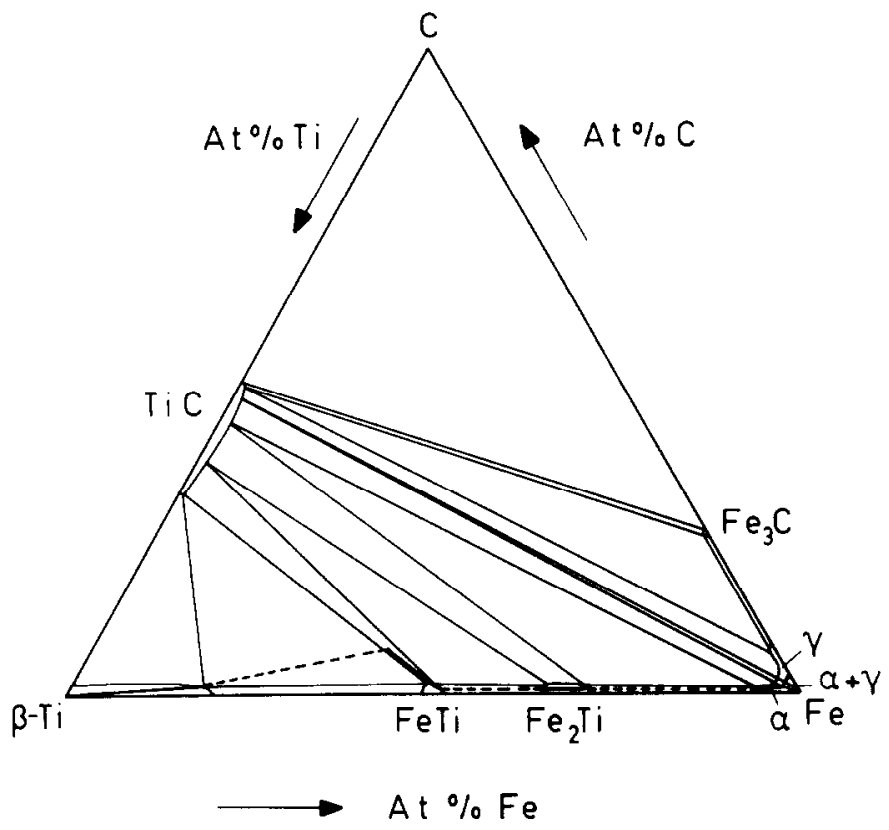

FIGURE 3 .

Observed diffusion path for couples Ti-Fe $100-y^{C} y$, $0.2<y<6.5$.

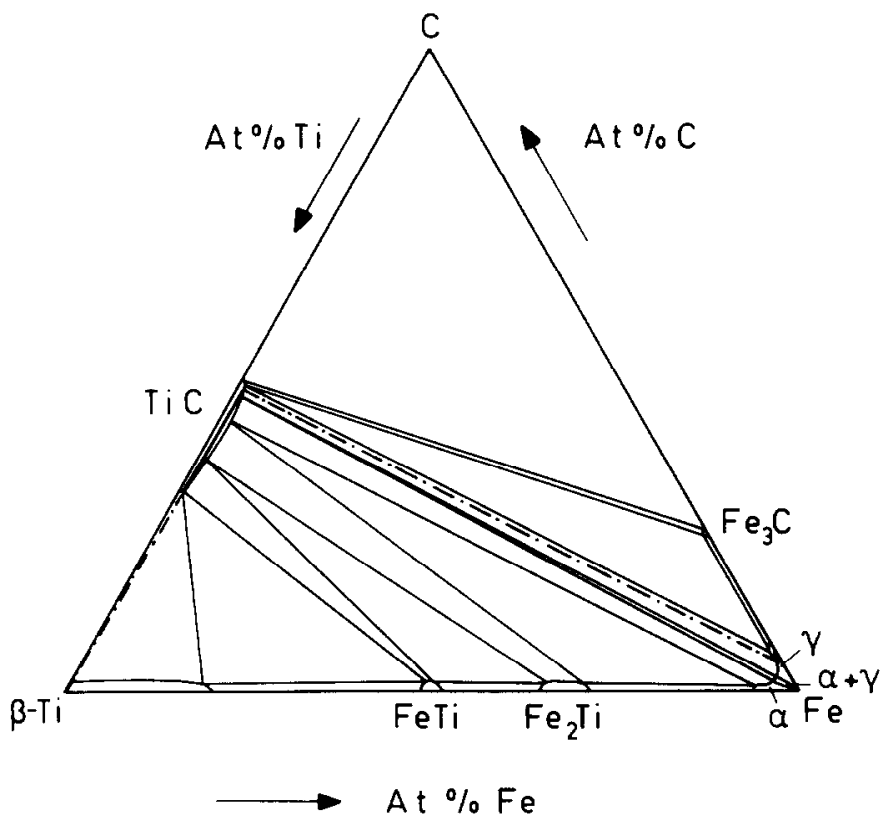

FIGURE 4.

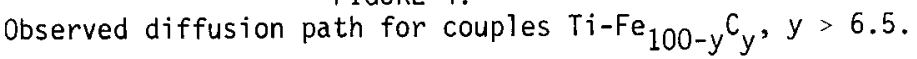




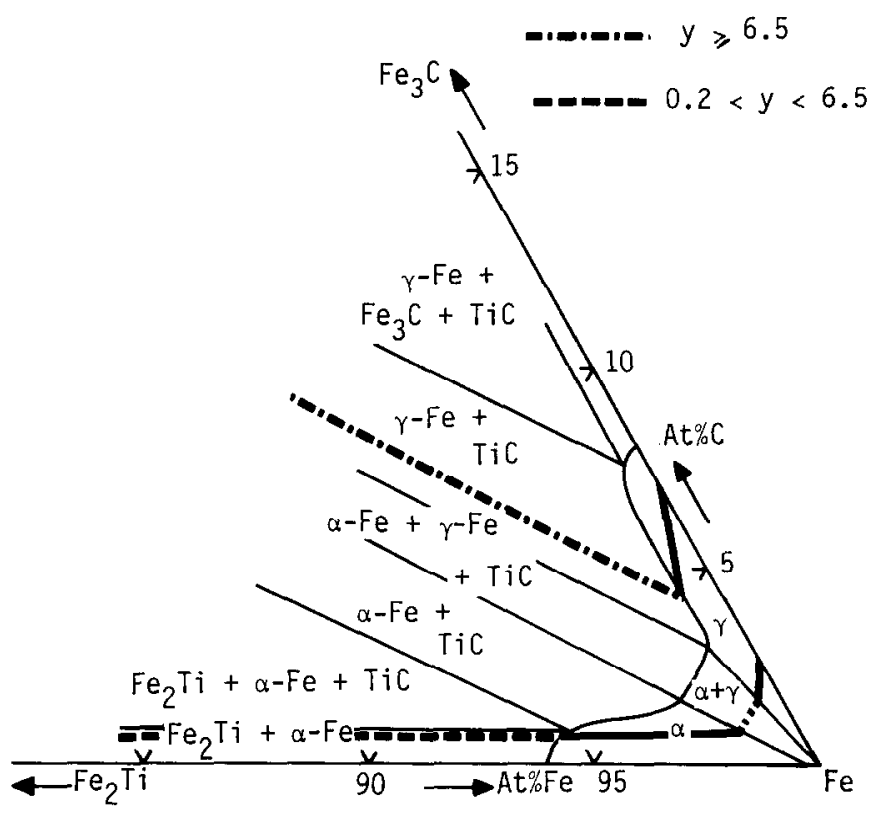

FIGURE 5

Enlargement of a section of figs. 3 and 4 , showing the decarburisation for couples $\mathrm{Ti}-\mathrm{Fe}_{100-\mathrm{y}_{\mathrm{y}}} \mathrm{C}_{\text {with } \mathrm{y}}>0.2$.

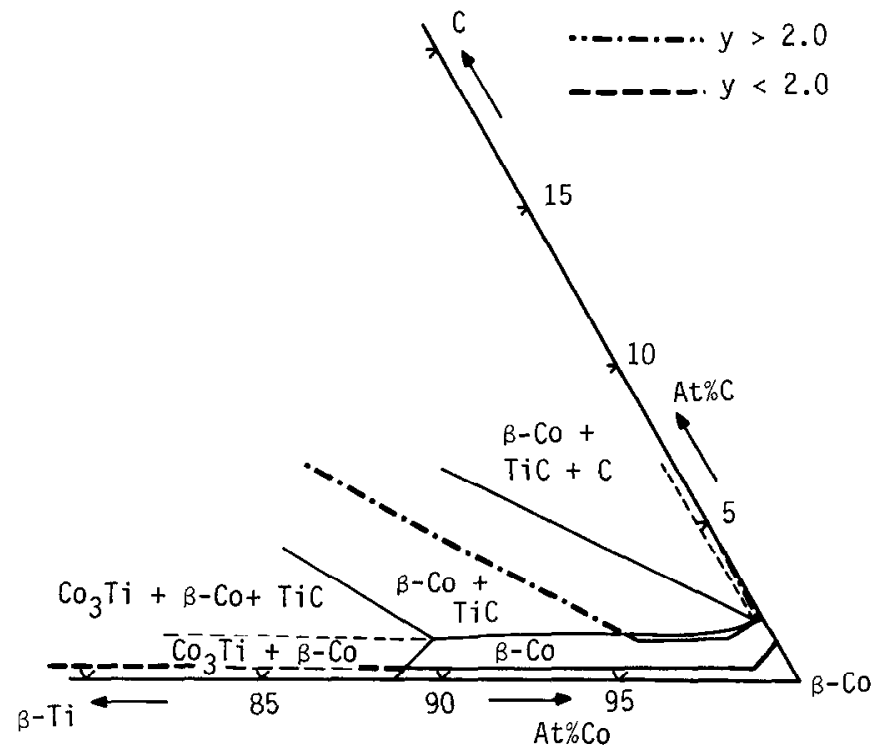

FIGURE 6

Diffusion paths in couples $\mathrm{T} i-\mathrm{CO}_{100}-y C_{y}$ showing the decarburisation of the cobalt starting material. 
The diffusion path in figure 5 for the case Ti-Fe ${ }_{100-y} C_{y}, y>6.5$ at. $\%$, actually is a normal composition profile determined by point measurements (EPMA) of concentrations in the single-phased $\mathrm{Fe}_{100-\mathrm{C}_{y}}$ material. However, in case of a two-phased starting material, like $\mathrm{Co}_{100-\mathrm{y}_{\mathrm{y}}}$ in figure 6 , a concentration profile based on point measurements by EPMA only gives information on the composition in both phases, but not on the number of precipitates as a function of distance (in the diffusion direction). This number is decreasing strongly in the direction of the TiC reaction layer (fig. 6), showing the strong decarburisation needed to form titanium carbide. So, in this case, the use of a composition profile, which is averaged over the observed phases, is indispensable. A diffusion path is then obtained (per definition) by plotting the average composition profile on a phase diagram cross section, thereby omitting the kinetic information.

Exactiy the same decarburisation profile as described in figs. 5 and 6 (for diffusion couples forming $\mathrm{TiC}$ ) has been observed when $\mathrm{TiC}$ coatings were applied to $\mathrm{Fe}_{100-\mathrm{y}_{\mathrm{y}} \text { or }}$ $\mathrm{Co}_{100-y^{C}} \mathrm{C}_{\mathrm{y}}$ substrates by $\mathrm{CVD}^{3}$. This strongly underlines the usefulness of (well-selected) diffusion couples as simulation experiments for CVD-treated samples.

\section{CONCLUSIONS}

Diffusion paths plotted on the isothermal cross sections $\mathrm{Fe}-\mathrm{Ti}-\mathrm{C}$ and $\mathrm{CO}-\mathrm{Ti}-\mathrm{C}$ reveal phenomenological information concerning the decarburisation process involved in the deposition of TiC on iron-carbon (or cobalt-carbon) substrates by CVD.

The usefulness of diffusion couples as analogs for CVD experiments has been demonstrated. As diffusion paths do not contain inherent kinetical information, a complete study of decarburisation phenomena should include a synthes is of diffusion path and compositon profile (as a function of distance) determinations.

\section{ACKNOWLEDGEMENTS}

We are greatly indebted to Mr. G. Verspui and Ir. M.M. Michorius of Philips CMT Eindhoven, The Netherlands, for the use of their CVD equipment.

The investigations were supported in part by the Netherlands Foundation for Chemical Research (SON) with financial aid from the Netherlands Organization for the Advancement of Pure Research (ZWO).

\section{REFERENCES}

1. P.J.M. van der Staten, M.M. Michorius and G. Verspui, Proceedings of the fourth European Conference on Chemical Vapour Deposition, eds. J. Bloem, G. Verspui and L.R. Wolff (Eindhoven, The Netherlands, 1983), pp. 553-567.

2. P.P.J. Ramaekers and F.J.J. van Loo, this volume, pp. 546-553.

3. P.P.J. Ramaekers, G.F. Bastin and F.J.J. van Loo, Proc. of the tenth International Symposium on the Reactivity of Solids, Dijon 1984 (North-Holland, Amsterdam, 1984) in print.

4. P.P.J. Ramaekers, G.F. Bastin and F.J.J. van Loo, Z. Metallkde. 75 (1984) 639.

5. P.P.J. Ramaekers, F.J.J. van Loo and G.F. Bastin, this volume, in print.

6. J.S. Kirkaldy and L.C. Brown, Can. Metall. Q. 3 (1963) 89.

7. J.B. Clark, Trans. Metal1. Soc. A.I.M.E. 227 (1963) 1250.

8. M.A.J.Th. Laheij, F.J.J. van Loo and R. Metselaar, 0xidation of Metals, 14 (1980) 207.

9. R.A. Rapp, A. Ezis and G.J. Yurek, Metall. Trans. 4 (1973) 1283. 